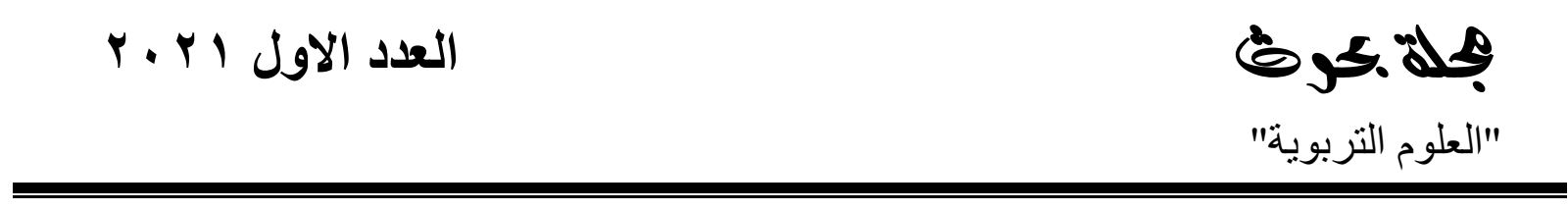

\title{
Language learning and Identity barriers: The story of Saudi Students in the UK educational settings.
}

\section{Sumayyah Soliman Alghezzi*}

DR Esther Asprey**

\begin{abstract}
:
This qualitative paper examines the identities of Saudi students who come to study for higher education qualification in the UK. It aims to shed light on how Saudi learners encounter a new culture and engage within the community and how this interaction affects their complex identities for the purpose of learning. The aim of this research is to obtain an understanding of Saudi learner's' sense of self and how culture affects them; thereby enabling the development of strategies to encourage the investment in the target culture through the process of learning the language. This study was conducted by using semi-structured interviews and questionnaires with female and male Saudi students. The results highlighted the importance of the target culture for language learning, as well as how the conflict between two cultures has resulted in a rejection of investment in language learning. Nonetheless, it is clear that many other variables affect an individual's adaptability to the new culture; this aspect is not unique to Saudi learners.
\end{abstract}

Keywords: identity, language learning, culture, transition, Saudi learners, investment.

\section{Introduction:}

Studying abroad is an interesting experience which has many effects \& challenges on people's identities and their perception of self. Many studies have been conducted in the field of identity and language education (Norton, 1995; Menard-Warwich, 2007; De Costa, 2011) However, gaps in this area need to be filled. For example, the cases of Saudi identity and language learning still need to be addressed. Many studies were conducted by non-Saudis. However, they did not provide an accurate portrayal of Saudi communities. In addition to that many studies neglect the Saudi culture as a vital element of the Saudi identity. Thus, it is believed that there is an urgent need to delve into the complex identities of Saudi learners who live in the UK. So as to shed light on the Saudi identity in terms of language learning.

The focus of this paper will be on the notion of identity as a flexible concept rather than a fixed product. The results that was reported by Campbell, Mare and Walker (1995) about the

\footnotetext{
*Master of English and Linguistics, Birmingham University

Lecturer at the department of English literature, College of Education for Girls, Zulfi, Majmaah University

** Assistant professor English and Linguistics, Birmingham University

Email: s.alghezzi@mu.edu.sa
} 
transformation in the identities of the workers, when they start replacing their traditional customs with modern Christian traditions is a great indicator of the different roles that humans adopt into their lives according to their social communities. Therefore, it will result in a change in their identities to become more adaptable to their surroundings.

\section{Research Problem:}

The researcher observed that Saudi students suffered while using the language to communicate with friends and colleagues as well. A search of the literature revealed few studies which focused on identity \& language learning not so many related to the importance of cultures, beliefs and religions of the students with a contrasting culture like the UK. Limited literature addresses Saudi identities and language learning, much of which describes studies conducted by non-Saudis; therefore, it did not provide an accurate portrayal of Saudi students. In addition, the studies reviewed by the researcher did not focus primarily on Saudi culture as an important element of Saudi identity. Thus, it is believed that there is a need to draw a fuller picture to understand the complex identities of Saudi learners who live in the UK. In an attempt to find a solution for this problem, the present research will investigate the relationship between Saudi identity and learning English language. It also shed light on the importance of the target culture in language learning, and whether a person's identity may affect their progress in learning the language effectively.

\section{Significance of research:}

The current research attempted to understand the complex identities of Saudi learners who live in the UK to facilitate their own learning process. By discovering how learner's identity affect the language learning, different strategies could be used by beneficiaries for Pedagogical Implications. It also helps the learners to express themselves more freely and in turn they can develop strategies for successful communication.

\section{Aim of the research}

This research was conducted to investigate the effect of identity on the process of learning the language. In order to investigate this issue, the research aims to answer the following questions:

1- What does learning a language involve?

2. Does learner's identity affect learning a language?

3. How do learners' identities affect their ability to learn a new language effectively?

\section{Definition of terms}

Identity: The concept of identity is not easy to define. In this research, a constructivist view was followed, in which identity is an ongoing process rather than a fixed one. For the aim of 
the study, identity was identified as: "multiple, changing, and a site of struggle" (Norton and Toohey, 2011: 414) It is formed by how people see themselves and how the world perceives them through factors such as religion, race $m$ gender and culture (AlAmrani, 2014)

Language learning: In this research second language learning is considered second culture learning. Second language learning is not only " grammatical competence, communicative competence, language proficiency" but also " a change in attitudes towards one's own or another culture" (Thanasoulas, 2001:1).

\section{Identity, language \& culture:}

Speech and values are inseparable parts of the person who produces them (Bourdieu, 1977). The way people identify themselves is hugely related to the way they speak. According to Norton (2010: p. 350) a person's speech cannot be understood without the social context. The accent and dialect a person use are great indicators of their association of class, gender, religion, ethnicity and their national communities. Ben-Rafael and Schmid (2007) have indicated that' language is one of the most important factors of identity and identification: people speak like the people they want to be like and use the way they talk to signal aspects of their own personalities.' This relation could be summarised as the 'language used as a vehicle to perform our identities that demonstrates multiple aspects of self, including our societies, cultures, histories and values' (Devereaux,2014:85).

\section{Identity, culture \& second language learning}

Learning or acquiring a language doesn't merely mean acquiring the linguistic system only, but it also includes the social interaction which affects personalities, personal values, identities and their views of the world around them. Both Hornberger (2010) and Norton (1997) asserted on the important relationship between identity construction and language learning. When language learners speak, therefore, "they are also constantly organizing and reorganizing a sense of who they are and how they relate to the world. They are, in other words, engaged in identity construction" (Hornberger 2010: 410). Researchers in the field of language education have investigated the relationship between identity and language learning. The concept of investment was one of the theories formulated in relation to this which was proposed by Norton (1995). She pointed out that high levels of motivation do not lead to better language learning or acquisition So, if a learner was highly motivated but with little investment in classroom then he or she may be regarded as a poor language learner. Similarly, Duff (2002) conducted a study on a multilingual school and revealed similar outcomes to Norton's. Such studies do confirm that demotivation is not the only reason for student's resistance to class participation. This may have been because they had little investment in the language practice of their class. Also, high-level learners could struggle with the culture of the class and prevent them from being fully invested. So, in order to have a true command of language, the person needs to conform to the culture of the native speakers. 


\section{Language learners in studying abroad}

More studies have been conducted on various issues concerning international students (e.g. Kubota \& Lin, 2009, AlAmrani 2014) since they create a beneficial opportunity for host countries. So, these countries should investigate multiple issues which affect student's adaptation to the values and the culture of the host country.

A lot of international students are caught up between two cultures; one that they know and familiar with and another which is practiced in the new country they live in. Therefore, these international students will experience many issues regarding the host culture as well as their own culture when trying to balance between both cultures on daily basis. so, a knowledge gap needs to be targeted to understand the identity of Saudi community and if it affects the process of language learning.

\section{Saudi Identity}

Clarke (2007) described Saudi Arabia as socially conservative Muslim country. For instance, public places are designed to keep unrelated men and women apart. Both religion and family are important factors that shapes Saudi's identity. Moreover, this influence is imposed from early age. Customs, traditions and tribal standards are important aspects of Saudi society. Yamani (2000) has referred to the importance of Saudi's role as not to dishonour their family name. So, their way of life creates a sense of identity and security.

In addition, it is important to discuss another feature in Saudi culture which is gender segregation. It is imposed in many domains in Saudi Arabia. It is "a cultural norm evident in almost every public and private institution...this phenomenon of gender segregation is central to most people's social, educational, and political activities" according to AlHazmi (2010: p.2) So, no contact is expected from both men and women. The only social network they have are confined to relatives or friends for males and females. However, within these recent years a great changes and social reforms have been introduced to the Saudi community by the crown prince Mohammed Bin Salman. So, one of these social and economic reforms is lifting the ban on women driving. By Allowing women to drive the numbers of Saudi females in the workforce will increase. Consequently, increasing the presence of women in public spaces, the traditional parts of the society will gradually change into new norms.

\section{Methodology:}

\section{Methods:}

The research examined the identities of Saudi English learners in the UK higher educational settings. It also aims to examine the effect of Saudi identity on their effective acquisition of the English language by using a survey and in-depth interviews. 


\section{Participants:}

The participants of this research were 55, 27 males and 28 females who participated in the open -ended questionnaire. All these participants are Saudis who live in different parts of the UK. Their ages ranged from 18 to 45 and the sample included undergraduates, postgraduate and those who are still learning the language before joining a university.

As for the interviews, 7 participants ( 4 females and 3 males) were interviewed who are friends and acquaintance. The interviews were advantageous in terms of being close and to understand their feelings and responses very clearly. The age range of these participants was between twenty-five and thirty-seven. Subjects live between Wolverhampton and Birmingham. As for the females, they were still studying post graduate courses in biology, business administration and TESOL. Two of them wear headscarves while the other two wear long dark dress (Abaya) and a veil to cover their faces except for their eyes. The male participants were still studying their course. Two of the participants are undergraduate of business management and one studies computer science.

\section{$\underline{\text { Data collection }}$}

The researcher began the data collection phase by reviewing the pilot study and by obtaining comments from peers and friends. The questionnaire and interview questions were prepared to begin the pilot study which was conducted with a friend and my husband. After conducting the interview, several mistakes were spotted, including missing and irrelevant questions. The questionnaire was distributed to another friend who reported several mistakes within the questions. By incorporating the feedback provided into the instruments, the researcher then started distributing the questionnaire which was initially written in English only. After receiving only, a small number of participants, an Arabic translation of the questions was added to make the process easier. At the beginning of data collection process, only received 14 and 10 responses for males and females were received, respectively. Some problems concerning the data collection of females' responses were encountered. It was therefore necessary to telephone several of them in order to obtain a balanced data sample.

\section{Results \& discussion:}

In this section, results of the interviews and the questionnaire are discussed. A thematic analysis was used as a primary tool to gain in-depth insight about the research questions. A tool that provides flexibility in identifying themes in different methods (Braun and Clarke, 2006). In data analysis and discussion, all the names of the participants are pseudonyms to ensure anonymity and confidentiality.

Three questions were addressed in the questionnaire and interviews:

1. What does learning a language involve? 
2. Does learner's identity affect learning a language?

3. How do learners' identities affect their ability to learn a new language effectively?

\section{Learning a second language:}

The findings from the questionnaire revealed that UK dwelling Saudi students' perceptions of the importance of learning a second language is quite varied. 27 of the 55 participants reported that learning a second language is extremely important, and 13 of the participants reported the opposite (see Table1).

Table 1. How much do you think it is important to learn a second language?

\begin{tabular}{|l|l|l|l|}
\hline $\begin{array}{l}\text { Importance of } \\
\text { learning a second } \\
\text { language }\end{array}$ & Male & Female & overall \\
\hline Extremely important & 15 & 12 & 27 \\
\hline Little important & 1 & 4 & 5 \\
\hline Slightly important & 1 & 0 & 1 \\
\hline neutral & 1 & 1 & 2 \\
\hline Slightly unimportant & 2 & 1 & 3 \\
\hline Little unimportant & 3 & 1 & 4 \\
\hline Extremely unimportant & 4 & 9 & 13 \\
\hline
\end{tabular}

The reasons presented for these choices differed, however the majority of the participants, even those who chose 'not important' as an answer, gave a reason. The choice might indicate that the decision to learn a second language was something imposed on them rather than a result of personal motivation. The participants' responses regarding the importance of learning a second language and its impact on them, whether male or female could be divided into three categories: being essential, economic, and educational purposes and reasons for learning a language included communicating, and being cultured. Their responses drew attention to two notions associated with motivation: instrumental and integrative motivation. With instrumental motivation, a learner is motivated to learn the language for a benefit or purpose (e.g. their job), while with integrative motivation a learner is motivated to learn the language to integrate with the language community (Norton,2000). The participants' major motivation to learn the language was instrumental; they chose to study English because it is an important tool to earn them a better job or education. Similarly, a number of the participants reported that learning English would provide an opportunity to engage with the whole world.

\section{$\underline{\text { Becoming Essential }}$}

Learning a second language was referred to in the answers as being essential in today's world. This theme was emphasized in their answers when they used words and phrases, such as: 
1. "There is a demand for learning an international language"

2. "To make your life better" because "English is the first language in the world"

By illustrating the participants views it becomes evident that the importance of learning a second language or English in particular is that it can lead them to answer the question of whether language affects participants' identities or not. As one of the male participants explained "it makes the person more successful in life, and helps him a lot in his career promotions or international business."

\section{$\underline{\text { Economic, educational reasons }}$}

Reasons for English being more essential than any other language for Saudi students could be both economic and educational. Many of the participants chose to study English because it is necessary for their future jobs or their higher education degree. In the case of Saudis, English provides an important tool to use for different opportunities. Many jobs in Saudi Arabia consider English an important requirement for job applicants; it "opens doors for good jobs". As for education, many Saudi students learn English to get higher education degrees in the UK or other English speaking countries. Furthermore, many journals, conferences, and universities around the world use English as main language for communication; it is according to one of the male participants "the language of this era". A clear example of this can be found in many Saudi universities (e.g. King Khalid University in Abha), which use English in addition to Arabic as an official language in their online websites.

\section{The language of communication}

Since becoming the language of the world, English now plays an important role, in addition to providing economic and educational status, as a means of communication for people from around the world. English is useful for participants when they travel, as it means they can communicate. For example, one of the male participants believes that:

It is the most important language now. If you go anywhere to a hotel, hospital and company they would communicate in the English language. Even computers, Online shopping, everything needs English. Whatever country you go to and whatever language they use; English is seen as the important means of communication.

Learning English, as learning any other language, makes people more aware of others around them. It improves their thinking, personality and makes it easier for them to understand other people. It is for one of the respondents a process of "mental enlightenment and broadening understanding" because it shows you different worldviews and different culture. Although for him it is a vehicle of communication specifically to understand the culture, this adds a new element to the idea of communication. This element of language as a vehicle for communication is not restricted to Saudi students only; it could involve students of different 
nationalities, Sri Lankans for instance, since English has become the language of international communication (Karunaratne, 2014).

\section{$\underline{\text { Impact on Learners }}$}

While speaking with the participants and reading questionnaire responses, many Saudis mentioned how English impacted them in a certain way. It appeared to the researcher that when concentrating on their answers their feelings toward English varied but many were positive. Learning and using the language, by becoming speakers of English, made some participants confident and proud of their improvements.

It is a good feeling and gives me confidence in what I know about my subject

At the beginning I felt that I had learned to communicate with locale [sic] people since I live in the UK, but then after I mastered it I feel like it has affected my personality in good way (it makes me feel more confident and more educated

Making me more confident

Similarly, learning English brought up other feelings and had different effects on the participants. Some participants believed that it was a way of progressing, either academically or socially and culturally. This impact was clear in one of the male participant's words, when asked about his feelings when speaking English "I...I feel that I have a different experience, a different way to talk, and a, another way to express myself." Similarly, English is "a chance to improve myself academically, socially and culturally, and that happens when socializing with other nations and other cultures". This is compatible with what Norton (2000) reported in her study of immigrant women in Canada. In the case of Martina, who was an immigrant mother and a worker, after a period of learning English, she was courageous enough to conduct her family deals and stop depending on her husband even with her little command of English. A similar result was reported in the immigrant story of Mai, who by using English changed her position at home, from a helpless girl, dependent on her brother to a language broker (Norton, 2000).

\section{$\underline{\text { Representative of oneself }}$}

Even though English has impacted them, many participants to a certain extent, reported that Arabic is still their representation. They had described how Arabic affects their selfrepresentation, as evidenced in the following excerpt, which shows that changing a person's ethnic identity is not usually possible:

202. Ok, I want to ask you about the language that represents you? Arabic or English? And why? 
Definitely, definitely my mother tongue, it represents me [why] first because it's my mother tongue which I was brought up on and if I think of my own language, I see it as my old language with its heritage and glory. It definitely represents me.

The Arabic language ... because I was brought on Arabic and studied in Arabic and I learned everything in Arabic ... it's my identity, I'm an Arabic man.

On the other hand, the other participants reported that, for them, English is a way of representing them in their jobs in Saudi Arabia. Two female participants believed that where they work in Saudi they use English more even with Saudi people because it represents their position.

Being here on the ground I see Arabic as representative of me or someone who represents Arabic. But in Saudi Arabia, English represents me more because it's the field in which I work. I am an English teacher till death and I'll be English teacher in Saudi.

\section{$\underline{\text { New Culture }}$}

The term culture is a vague concept and can include many things. For instance, culture according to Asuncion (1975:67) is "the sum total of learned behaviors of people which are transmitted from generation to generation", but for Bantz (1993:25) culture is "an outcome and a process that arises in the meaningful activity of people" (cited in Baldwin, Faulkner, Hecht and Lindsley, 2006:143). This theme is important for addressing the research question "What does learning a language involve? By exploring the meaning of culture to the participants, it could be said that culture is a very important part of language learning for them, and it may represent different meanings for the participants. The participants' view of culture is very broad, it includes religion, clothes, attitudes and activities. This theme is introduced here to shed light on the different aspects that create a UK culture from the perspective of the participants.

\section{$\underline{\text { Native speakers. }}$}

Many participants spoke about the theme of culture by discussing native speakers' attitudes. It was interesting that when talking about the UK culture the word 'native speaker' was present most of the time in a negative sense as "they don't welcome me", "not very friendly", and" people are cautious here and sadly not very friendly". As one of the female participants explained:

I don't like how they are concerned only with themselves, my work, my home and nothing else. 
Her statements embody one of Hofstede's (1980) four cultural dimensions: individualism, masculinity, power distance, and uncertainty avoidance. Individualism-collectivism dimension describes how people define their relationships with others. From her description ,the British culture is an individualistic culture where ties are loose and people's main concerns are themselves and their immediate family (Jandt, 2009). This culture contrasts with Saudi values, as Saudi Arabia's is a collectivist culture, which values strong ties that connect each individual to the entire group or community. Therefore, it is difficult for a member of a tightly integrated culture, which emphasizes relationships among people to assimilate the values of individualistic cultures.

\section{$\underline{\text { Freedom }}$}

Another aspect of the UK culture which contrasted with Saudi culture was 'freedom'. The word freedom includes many concepts, such as speech and independence. It provided the freedom to talk, which was not found in their culture and freedom to be independent, which was mainly stated by female participants and expressed from a positive perspective.

The UK's culture is an open culture; there are things that I like about it (e.g. freedom of speech).

The UK is an open-minded country compared to Saudi, especially for us women... I can do all my duties without help from anyone... but in Saudi it's difficult to go out.

\section{Becoming bicultural (New Saudi identity)}

Many participants described how they were engaged with the new culture in order to learn the language. Many reported that they had gained new skills, characteristics and behaviors that they never had before. However, they did not absorb everything from in the UK culture, only those components that accord with their values and religion, and many had mentioned that this was imposed on them rather than being accepted on their part. An example is evident in the changing time management habits of Saudis, as, for instance, many are not really concerned with arriving on time for an appointment.

Yeah we have taken something from their culture, to be always respectful of time, use email to contact them ... what we do now are the things that we should have done before.

You feel that you are affected by them...time management, having priorities and that is something I've learned here ... all of these things are imposed on us ... then I started to accept it ... and then it was part of my behavior.

This section shows that becoming bicultural does not really mean having a Saudi-British identity, because both cultures are different and contradictory. Many people believe that 
adopting time management strategies is just a temporary shift that will change when they return to Saudi. However, others were convinced that having cultural values like independence is something that will not change even upon their return to Saudi. The following quote indicates that:

It might be positive things for many pepole, but for me as Norah i see it as something negative. We are from Saudi and you know our condition there. We, in Saudi are not forced as females to serve ourselves or be dependent on ourselves. But here and because of their equality, men are the same as women. They don't consider a woman's psychological or even physical state as being different from the man. It's not necessary that she can bear everthing. I can say that this is tiring thing, very tiring. I mean, I mean, ... $i$ con't have to do that by myself, which means my father, my brother will always do everything for me... but suddenly I have to find an apartment by myself, go to an estate agent and they don't accept my father to sign instead of me, I should go to the Bank. They don't even respect me as a female when I need help carrying heavy things: just go and carry things because they are yours. I remember when I was at London airport, I was carring alot of luggage and I was surronded by a huge number of men but no one did came to help me carrying anything, while in Jeddah there are workers who do this service. Secondly there was a man who I didn't know; once he noticed me he asked me where's my bag and then he carried it and put it on the trolley for me, and then he walked away. In our tradition, they do respect women, which is missing here. Women here are treated like men without any concern for their psychological or even physical state; it's a bad thing. The second point is that this habit seems to become implanted. I will need to do everything by myself when I go back to Saudi I won't be pampered (laughs). I have become a man (laughs) - it's official

While living in British culture and experiencing multicultural societies, some Saudis still believe that Saudi culture is immune from flaws. A key reason for this is the participants' perception of Saudi culture as the culture of Islam. The following excerpt explains this idea:

Saudi culture represents Islamic identity, which means Islamic culture. Not only Saudi says this, even most Muslims around the world... Saudi's culture is Islamic.

This aspect of culture cannot be overstepped most of the time and the example is apparent from Saudis perception of desegregation. One participant reported that, the "Saudi community are known to be Muslims...males and females don't communicate in the way they do here... what I have mentioned is considered part of the religion."

\section{Cultural barriers to language learning:}

Desegregation

Another component of UK culture is the desegregation of women and men in many places in the country and especially at Universities, which differs from Saudi Arabia. In Saudi, many 
universities accept only females or only males, and that also includes the staff. The new mixed gender environment can be very confusing for Saudi students, since previously they rarely had contact with the other gender except for relatives. A number of the participants reported that mixed classrooms cause a barrier to their language learning. When asked about their feelings, the number of participants feeling uncomfortable in mixed classrooms was 7 out of 28 for females and 4 out of 27 for male participants, which is considered a very low number of overall survey participants. This result, in fact was unexpected because gender segregation found in Saudi in many domains. However, it can be noted that the response regarding being uncomfortable was mainly received from the participants who had lived less than a year in the UK and who had not become accustomed to the practice. However, that does not indicate the approval of the others who realize that it is common. Even though there were some participants who considered mixing good and natural, many declared that it is acceptable, only in the UK but that it does not change their view on gender segregation in Saudi Arabia. Most of the participants reported that they accepted it because it is imposed on them by the British culture. The following are the responses of two female respondents about their feelings toward mixed classrooms.

(Laughs) not comfortable, but we must respect that.

It is considered an advantage for Saudis when they separate men and women; this is considered an advantage and a freedom so females can behave in the way they like. At the beginning, talking in front of males or discussing things in front of them... it was the most difficult thing but now and over time it became alright.

Even though many individuals reported that they accept this situation to some extent, it appears that Saudi males and females choose not to overstep their cultural boundaries. Tables 2 and 3 show male and female responses regarding who they would prefer to sit next to in a class.

Table 2. Figures for ranking the preferable person to sit next in a class for Males

\begin{tabular}{|l|l|l|l|l|}
\hline $\begin{array}{l}\text { Male } \\
\text { participants }\end{array}$ & First choice & Second choice & Third choice & Fourth choice \\
\hline Saudi male & 6 & 9 & 9 & 3 \\
\hline Non Saudi male & $\mathbf{1 5}$ & 7 & 3 & 2 \\
\hline Saudi female & 3 & 3 & 8 & 13 \\
\hline NonSaudi female & 3 & 8 & 7 & 9 \\
\hline
\end{tabular}

Table 3. Figures for ranking the preferable person to sit next in a class for Females

\begin{tabular}{|l|l|l|l|l|}
\hline $\begin{array}{l}\text { Female } \\
\text { participants }\end{array}$ & First choice & Second choice & Third choice & Fourth choice \\
\hline Saudi male & 3 & 3 & 4 & 18 \\
\hline Non Saudi male & 0 & 10 & 12 & 6 \\
\hline Saudi female & 13 & 5 & 8 & 2 \\
\hline NonSaudi female & 12 & 10 & 4 & 2 \\
\hline
\end{tabular}


Both tables show that the least preferable person to sit next to in a class would be a Saudi male for a Saudi female and vice versa for males. The following quotation from a male participant on cultural barriers for language learning explains this:

Sometime my partner in the classroom is a Saudi female, and because of misunderstanding Islam and because of some wrong cultural beliefs my partner will not practice the language with me, although she feels very comfortable with nonSaudis, as I do too.

\section{Communication with people}

One of the barriers that most of participants emphasized related to ease of communicating with native speakers. Many reported that communicating with native speakers helped them develop their language to some extent, but they reported that many native speakers were unfriendly and unsociable.

Building a relationship is very hard with English people.

We can't form a friendship with native speakers due to their culture! In my opinion, I think practicing language with native speakers would lead to noticeable improvement.

However, others reported that this difficulty forming bonds with native speakers could relate to the city being accustomed to the presence of international students or not. As observed by a male participant, who studied the language in two different cities in the UK:

In Oxford for example, they welcome students and if I had a problem they would correct me because they know that I'm here to learn the language, there are many language institutes and a lot of host families that accept students.... They are not used to students in Wolver Hampton; if we look for a rented house for a student they won't rent one for a student without an employed British man to sponsor them.

Even though the cities mentioned in the participant's quote are both multicultural cities, this does not mean that Saudi people can expect to find friendships there.

As stated by the following respondent (1); she found difficulty making friendship with native speakers, commenting:

They are not quite flexible about our Islamic clothes... so it was difficult for us to find a native friend, and even when we found a native friend, her background was Islamic like us. We still acquire English but with an Islamic background.

Her statement could reveal that Saudi women who wear Islamic clothes (Hijab) might find a difficulty communicating with natives who are not Muslims like her. Respondent 2 is a Saudi Muslim student too, but she reported something different, that she had found many British 
people were quite friendly and helpful; she even stated that she is still in contact with a number of them.

I have a lot of teachers that I'm still in contact with on Skype and they are natives and I have two native friends for whom is English is their mother tongue... teachers or young British people, they have to work and they have little leisure time to talk with you and that's another problem.

The main concern that participant spoke about was for native speakers being busy with work and have limits on their time. This contradiction in views could result from their external appearance; Respondent 2 wears blue jeans and a long coat most of the time and covers her head with a colorful scarf, whereas Respondent 1 usually wears a long dark colored dress (Abaya) and covers most of her body except for her eyes. This might explain why few nonMuslim native speakers choose to communicate and befriend her. Moreover, when we compare women to men based on their external looks, it is much easier for men to make friendships with non-Saudis because they do not wear face coverings like Saudi women.

As for non-Saudi people, many of the participants reported that they learned two main things when spending their leisure time with them; these related to the language, and the culture of the person.

I practice my English with some British friends, so they help me to improve my English.

Their culture in regard to mine, the way they think may be...

However, when discussing Saudi friends, they stated that they receive practical support, language support, and cultural support. The following excerpts explain this:

I just learn from them how to adapt to these new things since we will share the same difficulties.

They are our family in this foreign country, and with their support we learn how to write our homework, what to do and not to do culturally, encouraging each other and helping each other in our studies

The second quotation clearly indicated that Saudis seem to create new familial ties, which bind them to each other and isolate them from mainstream culture. Based on Berry's model (1997) of acculturation, Saudi students appear to have a separate attitude toward UK culture, as they are more concerned with maintaining their home culture than engaging in, or having contact with UK culture. However, Berry's model did not account for Saudis attitudes regarding their separate attitude toward the culture. Saudis, as they reported, try first to integrate with the British culture, although they feel rejected by the unfriendly behavior of the 
British people. Many of the participants were not necessarily trying to stay within a Saudi cultural context; they just felt forced to do so.

A couple of the participants stated that they do not learn the language from Saudi friends, because "when they gather they would speak Arabic especially in a class... even though they are quite enthusiastic about learning the language, they would speak in Arabic"

Table 4. Preferable person to sit next in a class Males by rank

\begin{tabular}{|l|l|l|l|l|}
\hline Male participants & First choice & second choice & third choice & fourth choice \\
\hline Saudi male & 6 & 9 & 9 & 3 \\
\hline Non Saudi male & $\mathbf{1 5}$ & 7 & 3 & 2 \\
\hline Saudi female & 3 & 3 & 8 & 13 \\
\hline Non Saudi female & 3 & 8 & 7 & 9 \\
\hline
\end{tabular}

Table 5. Preferable person to spend leisure time with Males by rank

\begin{tabular}{|l|l|l|l|l|}
\hline Male participants & First choice & second choice & third choice & fourth choice \\
\hline Saudi male & $\mathbf{1 3}$ & 6 & 6 & 2 \\
\hline Non Saudi male & 10 & $\mathbf{9}$ & 5 & 3 \\
\hline Saudi female & 3 & 4 & $\mathbf{8}$ & $\mathbf{1 2}$ \\
\hline Non Saudi female & 1 & 8 & $\mathbf{8}$ & $\mathbf{1 0}$ \\
\hline
\end{tabular}

However, when looking at Table 4 and comparing it to Table 5, it emerges that the Saudi's first preference to go out with friends differs compared to the figures in the class, which indicates that going out might involve something they might reject like drinking alcohol. However, this is not restricted to rejecting British or Western habits; it seems from the following quotation that some of Saudi students prefer to engage more with international students than natives.

It is true that we feel a bit shy because they are natives. I mean we have to be silent more than talking to acquire and learn how natural conversation is performed... but as for Chinese and Japanese, our friends; it is comforting to be with them because we all are learning the language, our mistakes are forgiven by each other.

International students, regardless of whether they drink or not, are more preferable companions than natives. Both Saudi and international student have the same access level of English and similar understanding of cultural norms. Therefore, normally they feel more comfortable spending time with each other than with one of the natives. This is very common and not restricted to Saudis. A similar example is found in the experience of Anglophone centers, where international students tend to stay with each other rather than with local students (Liddicoat et al.2003, Preece 2011cited in Kirkpatrick, 2014). 
Table 6. Preferable person to sit next in a class Females by rank

\begin{tabular}{|l|l|l|l|l|}
\hline Female participants & First choice & second choice & third choice & fourth choice \\
\hline Saudi male & 3 & 3 & 4 & $\mathbf{1 8}$ \\
\hline Non Saudi male & 0 & $\mathbf{1 0}$ & $\mathbf{1 2}$ & 6 \\
\hline Saudi female & $\mathbf{1 3}$ & 5 & 8 & 2 \\
\hline Non Saudi female & $\mathbf{1 2}$ & $\mathbf{1 0}$ & 4 & 2 \\
\hline
\end{tabular}

Table 7. Preferable person to spend leisure time with Females by rank

\begin{tabular}{|l|l|l|l|l|}
\hline Female participants & First choice & second choice & third choice & fourth choice \\
\hline Saudi male & 3 & 2 & 8 & $\mathbf{1 5}$ \\
\hline Non Saudi male & 0 & 5 & $\mathbf{1 5}$ & 8 \\
\hline Saudi female & $\mathbf{2 0}$ & 4 & 2 & 2 \\
\hline Non Saudi female & 5 & $\mathbf{1 7}$ & 3 & 3 \\
\hline
\end{tabular}

Similar results are shown for females in Tables 6 and 7 , even though the figures for $3^{\text {rd }}$ and $4^{\text {th }}$ preference were clear cut in Table 6, unlike the figures for Saudi men in Table 5. For males, these results do not correspond with responses to the question 'who do you spend most of your time with? 22 of the total 27 participants responded that they spend most of their time with Saudi friends. However, in reporting their preference, 11 out of the 27 preferred going out with non-Saudi as their first choice, which may indicate a mismatch between actual practice and desired practice. This act projects the participant's ideal identity, in which he is brave enough to do something, or wants the researcher to believe in it. In the case of Saudi females, they prefer a new culture and society, one in which persons of the same nationality can adapt more successfully; however, that does not help them to improve their language, since they speak Arabic with Saudi friends most of the time.

\section{$\underline{\text { Teaching methods }}$}

By asking the participants' views on the teaching methods used to teach the language (how do you feel toward teaching methods? Why? In what ways it is different to your teaching methods in Saudi and how) many found that teaching methods in the UK are beneficial to great extent (39 out of 41). When compared to the methods used in Saudi which mainly focus on the teacher as being the only source of information, the UK system follows a studentcentered approach which "focuses on self-study and self-development rather than teacher based style". This approach depends on self-learning and being critical; helping students to explore and look for information to some extent, rather than depending only on the teacher. Therefore, the main job for the teacher is to become a "facilitator or assistant" according to one participant, and that helps students to depend on themselves, helping their language to progress accordingly. 
Identity and the ability to learn the language

The last question that should be addressed here is: how does a learner's identity affect their ability to learn a new language effectively? Therefore, throughout this discussion of different aspects of Saudi students' identities and culture and its involvement in the UK culture, findings revealed that even those participants with negative attitudes toward the UK culture or system have a good level of language. For instance, Participant A as a female is not very comfortable with mixed classrooms, believes that this situation is a barrier to language learning, and spends her leisure time with Saudi friends on a daily basis. However, she received 6.5 in IELTS, even though she had been in UK for less than one year. Tables 8 and 9 show the IELTS scores for most of the participants.

\section{Table 8. Participants IELTS scores.}

\begin{tabular}{|l|l|}
\hline IELTS score & Number of participants achieving this score \\
\hline Don't remember & 1 \\
\hline 4.5 & 2 \\
\hline 5 & 5 \\
\hline 5.5 & 10 \\
\hline 6 & 14 \\
\hline 6.5 & 11 \\
\hline 7 & 5 \\
\hline 7.5 & 1 \\
\hline 8 & 1 \\
\hline
\end{tabular}

In the case of Participant B who lived in Reading city for 1-2 years, he has received 7.5 in IELTS and spends his time with non-Saudi people on a daily basis. However, Participant C who has lived less than a year in Leicester obtained 5 in IELTS, even though he has an issue with communicating with females in the class room as he reported. It is hard to know if speakers' self-reports are accurate (as cautioned by Trudgil, 1972). It seems from the previous data from Saudi participants that the degree to be invested depends solely on the identity of a person him/herself. The degree of being affected varies from person to person, and cannot be equal in all the cases of Saudi students, since many variables could be involved in the process such as time spent in the UK, length of time spent learning the language. For instance, Participant D who received 8 in IELTS and spent around 3 to 4 years in the UK, had a better score than others who had spent the same period in the UK. One of the reasons for her high score is that she already studied English in Saudi Arabia and her major was American literature in which English was used as the language of instruction. So, it seems that many variables can affect a person's ability to learn the language in addition to their investment in the target culture and language.

Appendix C refers to participants who have lived in the UK less than a year; it compares their attitudes in many aspects of the UK, including culture, mixed classrooms and their interactions and social relations. The female participants all received 6 and higher scores in 
IELTS despite complaining of suffering from conflict and inconvenience when coming to the UK. However, the male participants who complained of the situation in the classroom and criticized the culture received 5 in IELTS, and the one who was happy received a 6 . This result may indicate that females are more adaptable or better at succeeding in meeting their objectives. However, this result is not representative of all Saudi females in the UK and much more research should focus on discovering whether these findings are transferrable to other contexts.

\section{Conclusion:}

This research was first planned to investigate whether a learner's identity may become a barrier to the process of learning English. By examining a learner's identity, a language learning theorists is able to address the power relations of the entire social world, thereby affecting a learner's access to the target language community. Since learner identity is very important for language learning, this research aimed to provide greater knowledge on the issue of identity and its relationship with language learning.

The first theme which emerged was the importance of defining culture which relates very deeply to the language learning process. Findings revealed that Saudis understood the British culture in terms of the attitudes of native speakers and the act of freedom. The clash between Saudi Arabia's collectivist culture and Britain's individualistic culture resulted in Saudi's expressing negative views of British people, which in turn may cause insufficient communication between the two parties. Similarly, freedom emerged as a theme because Saudi participant raised it as a component of British culture. Their perception of freedom, either of speech or personal movement and independence was positive. It seems that it created individuals that are more independent which in turn adds to their identities as Saudis and changes it. Furthermore, it seems that engaging with the culture prompted a new sense of self, blending Saudi and British values. Part of these values associated with time management. However, Saudis reported that this appears something temporary that might change once they return to Saudi Arabia. This is because time is not valued in eastern countries, as it is in Saudi Arabia, as primarily valued in western countries (Haque, 1997). However, independence feature which was reported by Saudi women, have become part of them willingly or not.

Another finding was their lack of engagement with the UK culture and resulted noninvestment in language learning as Norton (2000) had indicated before. Saudis who came from a gender segregated environment find mixing with other genders both inconvenient and uncomfortable. Even though many reported that it is not considered an issue while learning, it seems that this is not always the case, especially between Saudi females and males.

A similar hurdle was communication with native speakers and international students. It seemed for Saudis that native speakers (UK first language English speakers) are not very sociable, which prevents them from making friends with them. Several participants believed 
that this is because of the city they lived in, while others thought that the Saudi women's dress code makes native speakers unfriendly. Saudis engage with other international students to learn the language. Although Saudis prefer to speak and engage with other international students who share the same level of English and similar cultural norms, the majority of the participant spend their leisure time with students of the same nationality. This finding is not unique to Saudi and it is also observed among people of different nationalities.

Generally, it can be observed that Saudi students who live in the UK struggle with various things in order to learn the language. Saudi identity consists of religion and culture clashes with British culture and classroom practices. Because of little investment in the classroom practice and discomfort, Saudis' suffer from communication difficulties with natives; thus, it seems that a Saudi student's abilities to learn the language effectively are affected. However, that does not mean that Saudi students cannot overcome such barriers. Many participants got high scores in their English proficiency Examination (IELTS, TOFEL, etc.), indicating that barriers can be overcome with suitable support and persistence in their experience of learning the language.

\section{Limitations of the study:}

There are some limitations found in this study. The main limitations might be that this study cannot be generalized to all international students because of the different cultures from which they originate. Similarly, it is difficult to generalize a UK based study to the experiences of Saudi students in different countries like the USA, due to the different culture there. Moreover, my position as a female Saudi researcher is problematic to some extent. Although being a Saudi establishes a common ground between the researcher and the participants, it also creates a natural bias toward the Saudi perspective. On the other hand, my success as a female Saudi fieldworker is limited when contacting male participants, because cultural boundaries prevent women from speaking to unrelated males, which makes it difficult to really investigate Saudi men's views and perspectives.

\section{Implications and recommendations:}

This research could help to explain why some Saudis fail to invest in language learning. The UK as a country receives a huge number of international students, and should really consider how to make these students more involved with the British culture, by offering them more extensive understanding, and continued support. It is also the responsibility of universities to prepare a suitable environment and welcoming staff as far as possible, such as encouraging gatherings and meetings with members of the native speaker community or other L2 English speakers. The university is a micro culture (Holliday, 1999) and could provide assistance to enable new students to engage with the wider UK culture, even though they cannot change the reality behind its borders. By understanding the identity of Saudis, UK teachers may not force 
Saudi men and women to work together, because it is difficult for them to overcome innate cultural boundaries.

Similar efforts need to be carried out by the Saudi government who spends a lot of money sponsoring thousands of students to come to UK and complete their studies in different disciplines. Saudi officials should prepare Saudi students for the new environment and culture; an introductory program should be established to enlighten their perspective and enable them to be acquainted with the new environment in which they will learn the language. Therefore, officials need to focus more on preparing Saudi students to make contact with other students to prepare them socially and psychologically after arriving in the new environment.

Furthermore, it would be more interesting to explore in depth the female Saudi identity in the complex situation of an English course or a university course. This is because, Saudi women in particular encounter many restrictions in their home country; therefore, it would be interesting to investigate further how exactly they interact and negotiate with their social identities to achieve their language learning goals.

In general, findings revealed various problems faced by learners from a different culture when they come to the UK. Research questions should address how to overcome these differences by finding ways for both nations to work cooperatively to do so.

\section{References}

AlAmrani, G. (2014). Arab ESL Students at American Universities and their Identity

Formation Process. In Seawright, L. (Ed.) Going Global: Transnational

Perspectives on Globalization, Language, and Education (pp. 67-95). Newcastle

upon Tyne, UK: Cambridge Scholars Publishing.

AlHazmi, A. (2010). Saudi International Students in Australia and Intercultural

Engagement: a Study of Transitioning from a Gender Segregated Culture to a

Mixed Gender Environment. (Doctoral dissertation). Retrieved November 3, 2020 from https://www.researchgate.net/profile/Ahmed_Alhazmi2/publication/267801779_Saudi_Intern ational_Students_in_Australia_and_Intercultural_Engagement_A_Study_of_Transitioning_Fr om_a_Gender_Segregated_Culture_to_a_Mixed_Gender_Environment/links/551facc80cf2f9 c1304df701.pdf 
Baker, C. (2006). Foundations of bilingual education and bilingualism. (4th ed.)

.Clevedon: Multilingual Matters Ltd.

Baldwin, J. R., Faulkner, S. L., Hecht, M. L., and Lindsley, S. L. (Eds.). (2006).Redefining culture: Perspectives across the disciplines. London: Lawrence Erlbaum Associates

Ben Rafael, M., and Schmid, M. S. (2007). 'Language attrition and ideology: Two groups of immigrants in Israel' In Kopke, B., Schmid, M.S., Keijzer, M., and Dostert, S. (Eds.) Language attrition: Theoretical perspectives. Amsterdam: John Benjamins Publishing Company, pp. 205-226.

Berry, J. W. (1997) 'Immigration, acculturation and adaptation', Applied Psychology: An International Review, 46 (1), 5-68.

Berry, J. W. (2005)' Acculturation: Living successfully in two cultures' International Journal of Intercultural Relations, 29 (6), 697-712.

Bourdieu, P. (1977) 'The economics of linguistic exchanges', Social Science Information, 16 (6), 645-668.

Braun, V., \& Clarke, V. (2006). Using thematic analysis in psychology. Qualitative Research in Psychology, 3(1), 77-101.

Campbell, C., Mare, G., \& Walker, C. (1995)' Evidence for an ethnic identity in the life histories of Zulu speaking Durban township residents', Journal of Southern African Studies, 21(2), 287-301.

Clarke, K. (2007)' A modernization paradox: Saudi Arabia's divided society', Harvard International Review, 29(3), 30-33. Available at http://hir.harvard.edu/archives/1676 [Accessed 13 June 2015].

De Costa, P. I. (2011)'Using language ideology and positioning to broaden the SLA learner beliefs landscape: The case of an ESL learner from China', System, 39(3), 347-358.

Devereaux, M. D. (2014) Teaching about Dialect Variations and Language in Secondary English Classrooms: Power, Prestige, and Prejudice. Abingdon: Routledge.

Duff, P. (2002) 'The discursive co-construction of knowledge, identity, and difference: An ethnography of communication in the high school mainstream', Applied Linguistics, 23 (3), 289-322. 
Haque, M. (1997)'elements of cross cultural communication and the Middle East', In Kamalipour, Y. R. (ed) The US media and the Middle East: Image and perception. USA: Greenwood Publishing Group, 16-24.

Hofstede, G. (1980) Culture's Consequences: International Differences in Work-Related Values. Beverly Hills CA: Sage Publications. Holliday, A. (1999)' Small cultures', Applied linguistics, 20 (2), 237-264.

Holliday, A. (1999)' Small cultures', Applied linguistics, 20 (2), 237-264.

Hornberger, N. H. (2010) 'Language and education: A Limpopo Lens', In N. H. Hornberger \& S. Lee McKay (Eds.) Sociolinguistics and language education. Bristol: Multilingual Matters, 549-564.

Jandt, F, E. (2009) An Introduction to Intercultural Communication Identities in a Global Community (6th ed.) London: Sage Publications.

Karunaratne, S. K. (2014)' Student perceptions on learning English for personal and career development', International Journal of English Literature and Culture, 2(10), 250-256

Kirkpatrick, A. (2014) 'Teaching English in Asia and non-Anglo cultural contexts: Principles of the 'lingua franca approach ", In Marlina, R., and Giri, R. A. (Eds.). (2014) the Pedagogy of English as an International Language: Perspectives from Scholars, Teachers, and Students. London: Springer.

Menard-Warwick, J. (2007) '“Because she made beds. Every day.' Social positioning, classroom discourse and language learning', Applied Linguistics 29(2), 267-289.

Norton Peirce, B. (1995)' Social identity, investment, and language learning', TESOL Quarterly, 29 (1), 9-31.

Norton, B. (1997)' Language, Identity, and the Ownership of English', TESOL Quarterly, 31(3), 409- 429. http://doi.org/10.2307/3587831

Norton, B. (2000) Identity and Language Learning: Gender, Ethnicity and Educational Change. Harlow: Pearson Education Limited.

Norton, B. \& Toohey, K. (2011). Identity, Language Learning, and Social Change.

Language Teaching, 44 (04), 412-446. http://doi:10.1017/S0261444811000309

Rasmi, S., Safdar, S. and Lewis, J. R. (2009)'A longitudinal examination of the MIDA Model with international students', In Chybicka, A., Safdar, S., and Kwiatkowska, A. (Eds.) Culture 
and gender an intimate relations. Gdansk, Poland: Gdanskie Wydawnictwo Psychologiczne, $42-57$.

Thanasoulas, D. (2001). The importance of teaching culture in the foreign language classroom

Retrieved November 3, 2020 from https://radicalpedagogy.icaap.org/content/issue3_3/7-

thanasoulas.html

Trudgill, P. (1972) 'Sex, covert prestige and linguistic change in the urban British English of Norwich', Language in society, 1(02), 179-195.

Yamani, M. (2000) Changing identities: The challenge of the new generation in Saudi Arabia. Royal Institute of International Affairs, London: Chameleon Press.

\section{$\underline{\text { Appendix A }}$}

\section{Interview:}

\section{General information:}

What is your name? And how old are you?

Where are you from in Saudi?

How long have you been studying English?

Why did you choose to study English?

How do you feel toward English?

\section{Culture and environment:}

How do you feel toward British culture? Why? In what ways it is different to your culture and how?

How do you feel toward mixed classrooms? Why? In what ways it is different to your classrooms and how?

How do you feel toward teaching methods? Why? In what ways it is different to your teaching methods in Saudi and how?

\section{Friends and friendship:}

How do you feel when you spend your leisure time with your Saudi friends? Why? 
How do you feel when you spend your leisure time with your non- Saudi friends? Why? How did you know them?

What do you learn from people around you both Saudi and non-Saudi?

\section{English language:}

Did you take an English language test? What is your score?

What do you think about your language level?

If you think that you need to improve yourself what is your strategy to do that?

What are the difficulties that you face and affect your language learning?

Do you think that you have progressed since first you came here to the UK?

\section{Identity:}

What is your identity? Or who are you?

What is the difference between you now and before coming to the UK?

What is the Saudi culture in your point of view?

What is the language that represents you more? Arabic or English?

What is the language you use more? Arabic or English?

Do you think after returning back to Saudi that your actions, behavior will change?

\section{$\underline{\text { Appendix B }}$}

\section{Questionnaire:}

\section{Your age?}

2. $18-24$

3. $25-31$

4. $32-38$

5. 39 and more

\section{Gender?}


1. Male

2. Female

3. On a scale from 1-7, how likely do you think it is important to learn a second language?

Important. not important

4. Why important or why not important?

5. Do you study in the UK?

1. Yes

2. No

6. Where do you live now (in the UK)?

7. How long have you been in the UK?

1. Less than a year

2. $1-2$ years

3. 3- 4 years

4. 5 and more

8. Why did choose to study English language

9. How do you feel about learning English?

10. How long have you been studying English?

1. Less than a year

2. $1-2$ years

3. 3- 4 years

4. 5 and more

11. Did you take any English language test e.g. IELTS?

1. Yes 
2. No

12. What was your test and your score?

13. If you are still studying language please specify your level (beginner, intermediate, advanced ... etc.)

14. Thinking about the new environment you are living in; how do you feel about it?

1. Culture of the country

2. Gender mixed classrooms

3. Teaching methods

15. In a classroom, how comfortable do you feel?

Comfortable...... not comfortable

16. In what ways do you feel comfortable in a classroom?

17. In what ways do you feel uncomfortable in a class?

18. In your ideal classroom, who would you want to sit next to?

Please rank from 1 to 4

Saudi male

Non-Saudi male

Saudi female

Non-Saudi female

19. In terms of living in new culture, what do you learn from your Saudi colleagues? (Language, culture

20. In terms of living in a new culture, what do you learn from your non- Saudi colleagues?

21. Who would you like to spend your leisure time with?

Rank from 1 to 4

Saudi male 
Non-Saudi male

Saudi female

Non- Saudi female

22. Who do you spend your most of the time with:

1. Saudi friend

2. Non-Saudi friend

23. How many times do you see your friends?

1. Every day

2. Weekly

3. Monthly

4. Rarely

5. Other

24. Did you notice any cultural differences when you arrived to the UK?

1. Yes

2. No

25. If yes, how is this new culture different from your original background?

26. What are the cultural challenges you have faced in language learning?

27. Do you have any strategies to overcome these challenges?

28. What are your strategies?

29. Any comment, please be free to write anything necessary

Appendix C

Participants who lived in the UK less than a year 


\begin{tabular}{|c|c|c|c|c|c|}
\hline name & Sex & age & $\begin{array}{l}\text { IELTS } \\
\text { score }\end{array}$ & Live in the UK & $\begin{array}{l}\text { Attitudes toward culture, } \\
\text { mixed class rooms and their } \\
\text { relationship }\end{array}$ \\
\hline Yasser & Male & $36-45$ & 6 & Loughborough & $\begin{array}{l}\text { He is happy with engaging with the } \\
\text { British culture, find that mixed } \\
\text { classrooms ok and spend his leisure } \\
\text { time with non-Saudi firends. }\end{array}$ \\
\hline Obaid & Male & $26-35$ & 5 & Wolverhampton & $\begin{array}{l}\text { He is facing difficulty in engaging } \\
\text { with the culture and mixed } \\
\text { classrooms and spends his time with } \\
\text { Saudi friends daily. }\end{array}$ \\
\hline Abdulmohsin & Male & $18-25$ & 5 & Leicester & $\begin{array}{l}\text { He is still learning and engaging } \\
\text { with the culture but generally he } \\
\text { believes it is beautiful but for mixed } \\
\text { classrooms he feels it is awkward } \\
\text { and cause embarrassment and he } \\
\text { spends most of time with Saudi } \\
\text { friends daily. }\end{array}$ \\
\hline Ghadah & Female & $18-25$ & 6.5 & Southampton & $\begin{array}{l}\text { She believes that people here are not } \\
\text { very fiendly and mixed classrooms } \\
\text { are no different to her and she spends } \\
\text { most of her time with Saudi friends. }\end{array}$ \\
\hline Reem & Female & $26-35$ & 6.5 & Colchester & $\begin{array}{l}\text { She believes that learning British } \\
\text { culture is important for learning the } \\
\text { language. For mixed classrooms she } \\
\text { does not like it because she is not } \\
\text { used to it and she spends most of her } \\
\text { time with Saudi fiends. }\end{array}$ \\
\hline Dalal & Female & $26-35$ & 6 & Liverpool & $\begin{array}{l}\text { She believes that people here are } \\
\text { friendly and they have an open } \\
\text { culture. She also believes that mixed } \\
\text { classrooms is a way of teaching how } \\
\text { to communicate with each other but } \\
\text { still she is not comfortable with } \\
\text { sitting next to Saudi male. She } \\
\text { spends most of her time with Saudi } \\
\text { friends. }\end{array}$ \\
\hline
\end{tabular}


تعلم اللغة و حاجز الهوية : قصة الطلبة السعوديون في الأوساط التعليمية في المملكة المتحدة

$$
\text { سمية سليمان الغزي }
$$

ماجستير اللغة الإنجليزية و اللغويات من جامعة برمنجهام .

محاضر بقسم اللغة الإنجليزية، كلية التربية للبنات بالزلفي، جامعة المجمعة

s.alghezzi@mu.edu.sa

المشرف: DR Esther Asprey

أستاذ مساعد في كلية الأداب و القانون, قسم اللغة الإنجليزية و اللغويات بجامعة برنمجهام ( حالياً بجامعة

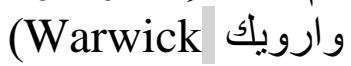

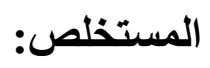

تعكف هذه الورقة البحثية الكيفية على در اسة هوية الطلبة السعوديين الدارسين للحصول على مؤهلات

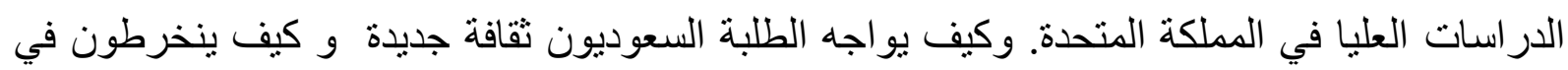

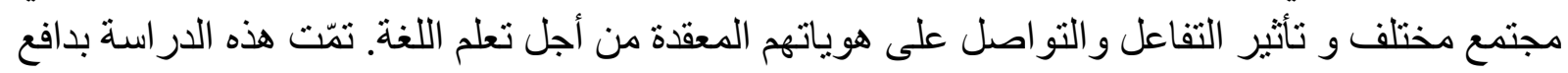

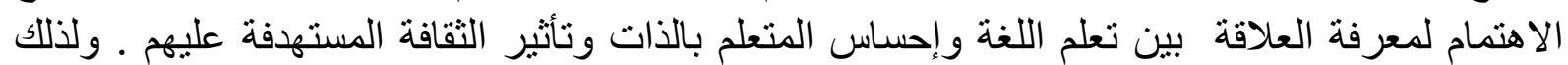

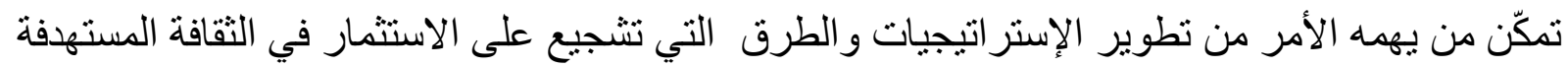

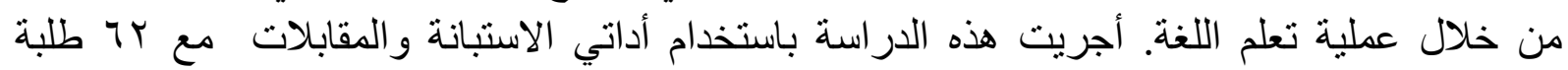

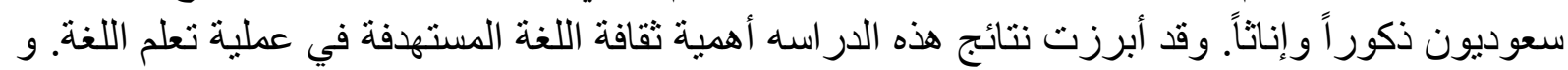

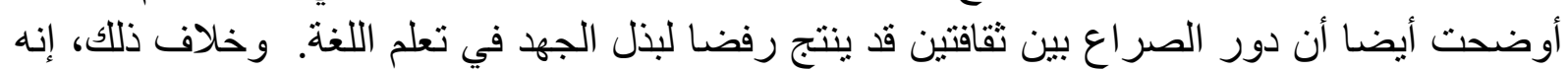

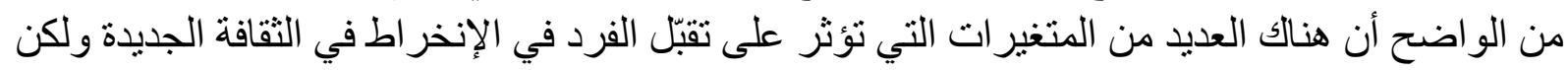

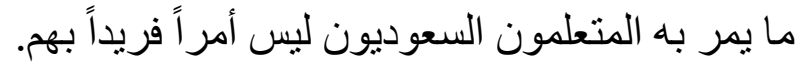

الكلمات المفتاحية : الهوية، تعلم اللغة، الثقافة، الانتقال، الطلاب السعوديون ، الاستثمار. 